\title{
Behaviour and Social Skills in Children Aged 3-5: Relationship with Sensory Processing
}

\author{
Margarida Isabel Araújo Oliveira ${ }^{1, *}$ and Helena Isabel da Silva Reis ${ }^{2}$ \\ ${ }^{1}$ Escola Superior de Saúde do Alcoitão, Rua Conde Barão, 2649-506 Alcabideche, Portugal \\ ${ }^{2}$ ciTechCare, School of Health Sciences, Polytechnic of Leiria, Portugal, Campus 2 - Morro do Lena, Alto do \\ Vieiro - Apartado 4137, 2411-901 Leiria
}

\begin{abstract}
Children with difficulties in sensory regulation show challenges in many areas, including externalized and internalized beahiour problems.

Methods: This study intended to determine the implications of sensory processing in the behaviour and in the social skills of 100 children, aged from 3-5, with typical development, through Sensory Processing Measure and Preschool and Kindergarten Behaviour Scales.

Results: Significant associations were found between sensory processing difficulties and behaviour problems, between the total of the spm-p scale and internalized behaviour problems $(p=.000)$; and the total of the spm- $p$ scale and externalized behaviour problems $(p=.000)$. The study showed a high prevalence of difficulties in sensory processing, not only in the home context but also in kindergarten, in undiagnosed children, with impact on multiple sensory systems. In children with dysfunction in sensory processing, it was possible to detect that hyporesponsive children have greater problems in terms of autonomy and the hiper-responsive ones have more difficulties in behaviour regulation.

Conclusion: It can be concluded that the higher difficulties in sensory processing the higher problems in the behavior are manifested in preschool children.
\end{abstract}

Keywords: Behaviour, Social skills, Preschool, Sensory processing.

\section{INTRODUCTION}

It is in the relation with the social environment that the child starts to find and experience new sensations; senses are the main tool to build sensorimotor development and perceptions, besides providing a solid base for the acquisition of intellectual knowledge, improving sensitivity and harmony with the first contacts with the outside world, that is, the environment in which the child in inserted. The practice of activities related to the sense organs, in addition to developing stimulation on the intellectual, psychological, cognitive and motor fields, addresses the children's emotional and social aspect, where they will learn how to socialize with the environment where they are inserted. [1].

Children who attend preschool should be able to coordinate the seven senses in order to learn about their world and act adequately. If the child does not correctly process the vestibular and proprioceptive information, they will have postural difficulties and fear when interacting with the challenges of the environment [2]. Therefore, school should offer a large

\footnotetext{
*Address correspondence to this author at the Escola Superior de Saúde do Alcoitão, Rua Conde Barão, 2649-506 Alcabideche, Portugal;

Tel: +351 21460 7450; E-mail: margaridaisabeloliveira@hotmail.com
}

and wide range of stimulations, because the environment contributes to the development of the child. Furthermore, the child's living conditions outside school should also be considered, for contributing to changes in the development $[2,3]$

All individuals need a good ability to process sensory information for a good performance in the environment and an effective participation in daily activities. However, behavioural functions can be affected by problems with sensory processing [4-6]. Children who have difficulties in sensory regulation show difficulties in many areas, including problems with externalized behaviour, internalizing behaviour problems, difficulties in emotional and attention regulation, as well as difficulties in many daily life activities and poorly developed adaptive social behaviours. The quality of interpersonal relationships may influence the social development of children of younger ages. Children who are not accepted by their peers are more lonely and more vulnerable to mental health problems in the future [4-10].

Gourley and his collaborators (2012) suggest that the functioning of sensory processing worsens the gravity of behaviour problems [4]. It should be highlighted that, even though there is comorbidity, sensory dysfunction exists regardless of the presence 
of internalizing and externalizing psychiatric disorders $[4,10]$.

The nosology proposed to characterize the Sensory Processing Dysfunction includes three categories. The first category is the dysfunction of sensory modulation, where hyperresponsiveness, hyporesponsiveness and sensory seeking are inserted. In the second category are included the dysfunctions of sensory discrimination, which may include deficiency in the ability to discriminate sensations in any sensory system, or across sensory systems, in a way that impairs occupational performance. In the third category, it is included the sensory-based motor dysfunction, where dispraxia and postural dysfunctions are described [11].

The sensory processing dysfunction is also related to emotional development and social problems, such as: fear, low self-esteem, isolation, among other factors. These conditions imply the loss of social and cognitive interaction necessary for healthy development. These difficulties in sensory processing cause impairments both in the motor and behavioural development, as well as in learning $[12,13]$.

The child's integration in to kindergarten has a significant impact on socio-emotional behaviour. Children may feel discomfort with new experiences, changing from the family context to the educational context, and behavioural changes, such as tantrums, refusal, isolation or avoidance of new situations may occur [14]. Preschool environments are richer in physical and social stimuli which frequently cause significant stress to the child [15].

Parents tend to identify more behaviour problems and higher results for social skills in children in comparison with the results obtained by kindergarten teachers [12-14]. However, although parents may identify and face problems at home long before children enter kindergarten, sensory issues can become much more evident when the child enters the preschool environment [15].

The main problems currently mentioned in clinical practice with children reflect concerns about adapting to different contexts, the refusal to take part in certain activities and situations, difficulties in interactions, social isolation, among others. These factors often trigger referencing for evaluation in the context of occupational therapy, at younger ages.

It should be mentioned that many studies show that difficulties in sensory processing are associated with behaviour problems in children with autism spectrum disorders, attention deficit and hyperactivity [6, 16]; but literature is scarce regarding the association of sensory processing with behaviour problems in the absence of developmental disorders. Considering the limitations of the subject in Portugal, the intention is to contribute to a better understanding of these difficulties in children without any diagnosis.

Given the above, the general goal of this study is to verify the relation between sensory processing and behaviour problems and social skills in children of preschool age in the absence of developmental disorders. It is also intended to identify the measure of sensory processing in children of preschool age, comparing the results obtained in the home context (by parents) with the kindergarten context (by teachers); to identify behaviour problems and social skills in children of preschool age; and to verify the relation between the sensory processing measure, behaviour problems and social skills in children of preschool age.

\section{METHODS}

\section{Sample}

The sample was made of children of preschool age, from 3 to 5 years old, who attended three kindergartens in the north of Portugal (one was private and two were Public Institutions of Social Solidarity-PISS), without previous diagnosis of any disorder that affects development. This is characterized as a nonprobabilistic, of convenience in relation to the choice of institutions, due to the contact and professional articulation previously established, which facilitated access to children. The 100 caregivers of the children that made up the sample and their respective kindergarten teachers (19 teachers: 11 from PISS, 8 from a private institution) also participated.

The sample consisted of 100 children from 37 to 71 months of age (average $=50,96, S D=9.418$ ), attending kindergarten for a period between three to 61 months (average $=26.75, S D=14.80$ ). Most of these attended a PISS $(61 \%)$, were of Caucasian ethnicity $(93.8 \%)$ and males $(53 \%)$. As for the kindergarten teachers, they were mostly females (88\%) and aged from 34 to 47 years old (average $=40.35, S D=2.865$ ) .

\section{Data Collection Tools}

The data collection was made with two assessment tools, namely the Preschool and Kindergarten Behaviour Scale - 2nd edition (PKBS-2), which is divided into two subscales (Social Skills and Behaviour Problems), validated for the Portuguese population; 
and Sensory Processing Measure - Preschool (SPM$\mathrm{P})$, home form and school form, whose semantic, conceptual, experimental and idiomatic equivalence has already been made [17].

The PKBS-2 was validated by kindergarten teachers and it is considered a clinically relevant tool for screening and assessing social skills and behaviour problems in children of preschool age, from 3 to 6 years old $[9,18,19]$. This scale was validated by kindergarten teachers who carry out teaching activity in kindergartens, consisting of 67 items, evaluated by a likert scale, with four levels of response, ranging from 0 (never), 1 (rarely), 2 (sometimes) and 3 (often). 0 means low social skills and low behaviour problems and 3 high social skills and high behaviour problems. The values are summed for each subscale, thus obtaining values that range from 13 to 87 points on social skills and values that range from 0 to 74 points, on behaviour problems. It consists of two subscales: the Scale of Social Skills (SSS), with 29 items, wherein the higher the values, the better social skills; and the Scale of Behaviour Problems (SBP), with 38 items, wherein the higher the values, the greater behaviour problems. The SSS consists of the dimensions: Social Cooperation, Social Interaction and Social Autonomy; the SBP is subdivided into the Externalized Behaviour Problems subscale (EBPS), (which includes the Selfcentered/Explosive, Excessive Attention/Activity Problems and Antisocial/Aggressive dimensions); and also the subscale of Internalized Behaviour Problems (SIBP) (consisting of the Social Avoidance and Anxiety/Somatic Problems dimensions). As for reliability, all scales of this tool showed robust values for internal consistency - Cronbach's alpha between 0,76 and 0,93 [9].

The SPM-P is meant for children aged from 2 to 5 and it is distributed in 75 items for each version (home form, which should be filled-in by parents/caretakers, and the school form, to be filled-in by kindergarten teachers), with four levels of response that vary according to the level of frequency with which the behaviours occur (between 1 meaning "Never", 2 meaning "Occasionally", 3 meaning "Often" and 4 meaning "Always"), and for some demographic issues $[9,20,21]$. Higher scores indicate greater difficulties at the sensory processing. This aims to determine whether the child's difficulties, together with sensory processing, harm the educational performance, also providing information related to praxis [22]. Both versions (home and school) are multidimensional and are composed of seven dimensions each: Vision,
Hearing, Touch, Body Awarreness, Balance and Motion, Planning and Ideas, and Social Participation, with a total of 75 items evaluated on each version. The scale's items are also sensitive to significant vulnerabilities in sensory integration, namely hiperresponsiveness. hyporesponsiveness, perception, sensory seeking, postural control, motor planning and ideation. Hyperreactivity usually manifests itself through fear, or aggressive behaviour or avoidance of certain sensory experiences; whereas hyporeactivity is the absence of expectable answers, apathy or indifference to sensory experience. "Sensory Seeking" is considered a hyporesponsiveness. According to Jean Ayres's theory, the child may seek stronger levels of sensory input in order to obtain a higher consciousness of the environment or this "Seeking" may also be the outcome of sensory deprivation. "Perception" is the ability to interpret the meaning of the sensory input and it is necessary to an effective and refined use of the feedback from the environment or from the internal sensory information. Praxis is the ability to idealize, plan and organise movements in order to do unknown motor tasks, and is divided into ideation (the ability to create a mental or conceptual image of a new task) and motor planning (the capacity to organise and plan new actions) [21]. The psychometric proprieties of the SPM-P indicate that the tool is able to distinguish children with typical development and children with sensory processing dysfunction [22].

\section{Procedures}

An authorization request was submitted to the previously selected kindergarten institutions, explaining the intended study, and it was requested permission from the authors for using the behaviour scales for preschool-aged children. Both requests were granted by the responsibles. Simultaneously, authorization was requested from the Western Psychological Services (WPS) for a possible use of the Portuguese version of the SPM-P. The authorization was approved with the right to use 100 copies through a contract signed between the investigator and WPS. Afterwards, a chart for demographic data collection was sent to kindergarten teachers; the informed consent, the SPM$P$ questionnaires - school form and behaviour scales. The documents sent to parents (informed consent and SPM-P home form) were made by the kindergarten teachers who, after meeting with parents, placed all the documentation inside the respective children's schoolbags. 
The questionnaires were randomly distributed to all children aged from 3 to 5 from the referred kindergartens, without any sort of diagnosis, and the sample was collected in order of participation, consent and completion by parents.

\section{RESULTS}

Table 1 demonstrates the comparison of the results obtained by the SPM-P home form (by parents) and the SPM-P school form (by kindergarten teachers).
The descriptive analysis of the sample's SPM-P in both contexts indicated that the problems of sensory processing are more common in the kindergarten context; and considering the total of the scale, $22 \%$ of the sample shows some problems/definite dysfunction in the home context, and $32 \%$ in the kindergarten context. It was observed that the problems on the Touch and Balance level were more frequent at home; whereas in kindergarten, the most frequent problems were on the Social participation and Vision levels. The Wilcoxon test found statistically significant differences in both contexts in these dimensions: Social

Table 1: Wilcoxon Difference Test between Home Form and School Form results, and the Respective Percentages of Children with Typical Development, Some Problems and Definite Dysfunction

\begin{tabular}{|c|c|c|c|c|c|c|c|c|c|}
\hline & \multicolumn{4}{|c|}{ HOME } & \multicolumn{4}{|c|}{ School } & \multirow{2}{*}{ wilcoxon } \\
\hline & $\begin{array}{c}\text { Typical } \\
\text { Development }\end{array}$ & $\begin{array}{c}\text { Some } \\
\text { Problems }\end{array}$ & $\begin{array}{c}\text { Definite } \\
\text { Dysfunction }\end{array}$ & Miss & $\begin{array}{c}\text { Typical } \\
\text { Development }\end{array}$ & $\begin{array}{c}\text { Probable } \\
\text { dysfunction }\end{array}$ & $\begin{array}{c}\text { Definite } \\
\text { Dysfunction }\end{array}$ & Miss. & \\
\hline $\begin{array}{c}\text { Social } \\
\text { Participation }\end{array}$ & $75 \%(75)$ & $\begin{array}{l}16 \% \\
(16)\end{array}$ & $\begin{array}{l}4 \% \\
(4)\end{array}$ & $\begin{array}{l}5 \% \\
(5)\end{array}$ & $\begin{array}{l}48 \% \\
(48)\end{array}$ & $\begin{array}{l}37 \% \\
(37)\end{array}$ & $\begin{array}{l}14 \% \\
(14)\end{array}$ & $\begin{array}{l}1 \% \\
(1)\end{array}$ & $\begin{array}{c}\text { School }<\text { home- } n=12 \\
\text { School }>\text { home } n=40 \\
\text { School }=\text { home } n=42 \\
Z=-4,170, p=0,000\end{array}$ \\
\hline Vision & $\begin{array}{l}67 \% \\
(67)\end{array}$ & $\begin{array}{l}20 \% \\
(20)\end{array}$ & $\begin{array}{l}4 \% \\
(4)\end{array}$ & $\begin{array}{l}9 \% \\
(9)\end{array}$ & $\begin{array}{l}48 \% \\
(48)\end{array}$ & $\begin{array}{l}33 \% \\
(33)\end{array}$ & $\begin{array}{l}16 \% \\
(16)\end{array}$ & $\begin{array}{l}3 \% \\
(3)\end{array}$ & $\begin{array}{c}\text { School }<\text { home- } n=11 \\
\text { School }>\text { home } n=32 \\
\text { School }=\text { home } n=46 \\
Z=-3,234, p=0,001\end{array}$ \\
\hline Hearing & $\begin{array}{l}66 \% \\
(66)\end{array}$ & $\begin{array}{l}21 \% \\
(21)\end{array}$ & $\begin{array}{l}2 \% \\
(2)\end{array}$ & $\begin{array}{c}11 \% \\
(2)\end{array}$ & $\begin{array}{l}56 \% \\
(56)\end{array}$ & $\begin{array}{l}34 \% \\
(34)\end{array}$ & $\begin{array}{l}5 \% \\
(5)\end{array}$ & $\begin{array}{l}5 \% \\
(5)\end{array}$ & $\begin{array}{c}\text { School }<\text { home- } n=16 \\
\text { School }>\text { home } n=24 \\
\text { School }=\text { home } n=45 \\
Z=-1,479, p=0,139\end{array}$ \\
\hline Touch & $\begin{array}{l}61 \% \\
(61)\end{array}$ & $\begin{array}{l}27 \% \\
(27)\end{array}$ & $\begin{array}{l}2 \% \\
(2)\end{array}$ & $\begin{array}{l}5 \% \\
(5)\end{array}$ & $\begin{array}{l}59 \% \\
(59)\end{array}$ & $\begin{array}{l}28 \% \\
(28)\end{array}$ & $\begin{array}{l}8 \% \\
(8)\end{array}$ & $\begin{array}{l}5 \% \\
(5)\end{array}$ & $\begin{array}{c}\text { School }<\text { home- } n=12 \\
\text { School }>\text { home } n=16 \\
\text { School }=\text { home } n=58 \\
Z=-1,100, p=0,271\end{array}$ \\
\hline $\begin{array}{c}\text { Body } \\
\text { Awareness }\end{array}$ & $\begin{array}{l}69 \% \\
(69)\end{array}$ & $\begin{array}{l}24 \% \\
(24)\end{array}$ & $\begin{array}{l}2 \% \\
(2)\end{array}$ & $\begin{array}{l}5 \% \\
(5)\end{array}$ & $\begin{array}{l}63 \% \\
(63)\end{array}$ & $\begin{array}{l}26 \% \\
(26)\end{array}$ & $\begin{array}{l}9 \% \\
(9)\end{array}$ & $\begin{array}{l}2 \% \\
(2)\end{array}$ & $\begin{array}{l}\text { School }<\text { home- } n=12 \\
\text { School }>\text { home } n=23 \\
\text { School }=\text { home } n=58 \\
Z=-2,468, p=0,014^{*}\end{array}$ \\
\hline Balance & $\begin{array}{l}53 \% \\
(53)\end{array}$ & $\begin{array}{l}19 \% \\
(19)\end{array}$ & $\begin{array}{l}18 \% \\
(18)\end{array}$ & $\begin{array}{l}10 \% \\
(10)\end{array}$ & $\begin{array}{l}62 \% \\
(62)\end{array}$ & $\begin{array}{l}21 \% \\
(21)\end{array}$ & $\begin{array}{l}15 \% \\
(15)\end{array}$ & $\begin{array}{l}2 \% \\
(2)\end{array}$ & $\begin{array}{c}\text { School }<\text { home- } n=24 \\
\text { School }>\text { home } n=22 \\
\text { School }=\text { home } n=43 \\
Z=-0,685, p=0,493\end{array}$ \\
\hline $\begin{array}{l}\text { Planning } \\
\text { and Ideas }\end{array}$ & $\begin{array}{l}81 \% \\
(81)\end{array}$ & $\begin{array}{l}10 \% \\
(10)\end{array}$ & $\begin{array}{l}4 \% \\
(4)\end{array}$ & $\begin{array}{l}5 \% \\
(5)\end{array}$ & $\begin{array}{l}58 \% \\
(58)\end{array}$ & $\begin{array}{l}27 \% \\
(27)\end{array}$ & $\begin{array}{l}12 \% \\
(12)\end{array}$ & $\begin{array}{l}3 \% \\
(3)\end{array}$ & $\begin{array}{l}\text { School }<\text { home- } n=6 \\
\text { School }>\text { home } n=30 \\
\text { School }=\text { home } n=56 \\
Z=-3,508, p=0,000\end{array}$ \\
\hline Total & $\begin{array}{l}56 \% \\
(56)\end{array}$ & $\begin{array}{l}19 \% \\
(19)\end{array}$ & $\begin{array}{l}3 \% \\
(3)\end{array}$ & $\begin{array}{l}22 \% \\
(22)\end{array}$ & $\begin{array}{l}55 \% \\
(55)\end{array}$ & $\begin{array}{l}27 \% \\
(27)\end{array}$ & $\begin{array}{l}5 \% \\
(5)\end{array}$ & $\begin{array}{l}13 \% \\
(13)\end{array}$ & $\begin{array}{c}\text { School }<\text { home- } n=11 \\
\text { School }>\text { home } n=14 \\
\text { School }=\text { home } n=43 \\
Z=-0,536, p=0,592\end{array}$ \\
\hline
\end{tabular}

School < Home - Number of subjects who have a higher rating in kindergarten than at home / School > Home - Number of subjects with a lower rating in kindergarten than at home / School = Home - Number of subjects with equal rating both at home and in kindergarten. 
participation $(Z=-4.170, p=.000)$, Vision $(Z=-3.234, p$ $=.001)$, Body Awareness $(Z=-2.468, p=.014)$ and Planning and Ideas $(Z=-3.508, p=.000)$, and it became perceptible that the worst results, in these dimensions, occur more in the kindergarten context than in the home context (see Table 1).

After selecting, in the sample, only children who showed some problems of definite dysfunction (according to the total of the home form and school form of SPM-P), it was possible to verify that, both at home and in school, the sample shows greater Hyperresponsiveness (school: 75\%; home: 81,8\%) than Hyporesponsiveness (school: 34,4\%; home: $31,8 \%$ ), and that the problems of Perception (school: 62,5\%; home: 63,6\%) and Ideation (school: 71,9\%; home: $68,2 \%$ ) and rather frequent. It should be noted that problems of Motor Planning are very prevalent in school $(78,1 \%)$; and that children with "Sensory
Seeking" at home $(77,3 \%)$ show high thresholds (Table 2).

Table 3 shows the results of the descriptive analysis of preschool-aged children's behaviour problems.

With regard to social skills, it was noted that most of the sample shows good social skills, with inferior percentages in the Low category (Table 3 ) being found in the Social Interaction (12\%) and Social Cooperation (14\%) dimensions.

As far as behaviour problems, considering the percentage of cases in the Low category, it was observed that, with the exception of the SBP Excessive Attention / Activity Problems (5\%), more than $50 \%$ of the sample shows moderate or high behaviour problems, in all the dimensions analysed by the scale. Nonetheless, it is in the SBP Anxiety Somatic Problems dimension $(69 \%)$ where the greater number of

Table 2: Descriptive Analysis of the Number of Children with Some Problems or Definite Dysfunction Distributed by each System

\begin{tabular}{|c|c|c|c|c|}
\hline \multirow[b]{2}{*}{ Sensory integration vulnerability } & \multicolumn{2}{|c|}{ School } & \multicolumn{2}{|c|}{ Home } \\
\hline & $\begin{array}{c}\text { Above average } \\
\mathrm{N}(\%)\end{array}$ & $\begin{array}{c}\text { Below average } \\
\mathrm{N}(\%)\end{array}$ & $\begin{array}{c}\text { Above average } \\
\mathrm{N}(\%)\end{array}$ & $\begin{array}{c}\text { Below average } \\
\mathrm{N}(\%)\end{array}$ \\
\hline Hyperresponsive & $24(75 \%)$ & $8(25 \%)$ & $18(81.8 \%)$ & $4(18.2 \%)$ \\
\hline Hyporesponsive & $11(34.4 \%)$ & $21(65.5 \%)$ & $7(31.8 \%)$ & $15(68.2 \%)$ \\
\hline Perception & $20(62.5 \%)$ & $12(37.5 \%)$ & $14(63.6 \%)$ & $8(36.4 \%)$ \\
\hline Seeking & $9(28.1 \%)$ & $23(71,9 \%)$ & $17(77.3 \%)$ & $5(22.7 \%)$ \\
\hline Postural Control & $14(43.8 \%)$ & $18(56.3 \%)$ & $7(31.8 \%)$ & $15(68.2 \%)$ \\
\hline Motor Planning & $25(78.1 \%)$ & $7(21.9 \%)$ & $9(40.9 \%)$ & $13(59.1 \%)$ \\
\hline Ideation & $23(71.9 \%)$ & $9(28.1 \%)$ & $15(68.2 \%)$ & $(27.3 \%)$ \\
\hline
\end{tabular}

Table 3: Results of the Descriptive Analysis for Behaviour Problems of Preschool-Aged Children

\begin{tabular}{|c|c|c|c|c|}
\hline & Low & Moderate & High & Missing \\
\hline SSS Social Cooepration & $14 \%(14)$ & $44 \%(44)$ & $40 \%(40)$ & $2 \%(2)$ \\
\hline SSS Social Autonomy & $20 \%(20)$ & $35 \%(42)$ & $44 \%(44)$ & $1 \%(1)$ \\
\hline SSS Social Interaction & $12 \%(12)$ & $42 \%(42)$ & $44 \%(44)$ & $2 \%(2)$ \\
\hline SBP Explosive Self-centred & $36 \%(36)$ & $38 \%(38)$ & $25 \%(25)$ & $1 \%(1)$ \\
\hline SBP Excessive Attention / Activity problems & $95 \%(95)$ & $0 \%(0)$ & $5 \%(5)$ & $0 \%(0)$ \\
\hline SBP Antisocial Aggressive & $45 \%(45)$ & $36 \%(36)$ & $17 \%(17)$ & $2 \%(2)$ \\
\hline SBP Social Avoidance & $38 \%(38)$ & $30 \%(30)$ & $29 \%(29)$ & $3 \%(3)$ \\
\hline SBP Anxiety Somatic Problems & $27 \%(27)$ & $41 \%(41)$ & $28 \%(28)$ & $4 \%(4)$ \\
\hline SBP Interiorizing & $33 \%(33)$ & $39 \%(39)$ & $23 \%(23)$ & $5 \%(5)$ \\
\hline SBP Externalizing & $39 \%(39)$ & $41 \%(41)$ & $18 \%(18)$ & $2 \%(2)$ \\
\hline
\end{tabular}


moderate or high problems can be found; the internalizing behaviour problems (SBP Internalized) are more evident $(62 \%)$ than the externalizing $(59 \%)$ (Table 3).

In order to verify the relation between the measure of preschool sensory processing, behaviour problems and social skills, a Pearson correlation of the Score-T was made, targeting the dimensions of the measure of preschool sensory processing (in school context), with the results of the scale of behaviour problems and social skills being completed by kindergarten teachers (Table 4).

Statistically significant positive correlations were found between all the SPM-P dimensions (Social Participation, Vision, Hearing, Touch, Body Awareness, Balance, Planning and Ideas and Total) and all dimensions related to behaviour problems; revealing that the greater the sensory difficulties, the greater the behaviour problems (Self-centred/Explosive, Excessive Attention/Activity Problems; AntisociallAggressive; Social Avoidance; Anxiety / Somatic Problems; Internalized Problems; and Externalized Problems).

Regarding the association between the measure of preschool sensory processing and social skills in preschool context, statistically significant negative correlations were found between all dimensions of the measure of preschool sensory processing and all social skills under analysis (Social cooperation, Autonomy and Social interaction); that is, the greater the sensory problems, the lower the social skills. The strongest correlations ( $r \geq 60$ ) were found between Social Participation and Social Cooperation $(r=-.805, p=$
$.000)$, Autonomy $(r=-.602, p=.000)$ and Social Interaction $(r=-.679, p=.000)$.

When analysing the correlations between the vulnerability systems in sensory integration in kindergarten (Hyperresponsive, Hyporesponsive, Perception, Seeking, Postural control, Motor planning and Ideation) and Skills and Behaviour Problems of the sample, with some problems or definite dysfunction, it was found that the more Hyperresponsive ones show less Autonomy $(r=-.418, p=.019)$, are more Antisocial/Aggressive $(r=.459, p=.009)$, show more Social Avoidance $(r=.505, p=.004)$, more Anxiety/Somatic Problems $(r=.427, p=.019)$ and more Internalization $(r=.571, p=.001)$ and Externalization problems $(r=.364, p=.044)$. The Hyporesponsive ones show less Social cooperation ( $r$ $=-.630, p=.000)$, less Social Autonomy $(r=-.547, p=$ $.000)$, less Social interaction $(r=-.416, p=.022)$ and more Social Avoidance $(r=.448, p=.013)$.

The Perception problems are more frequent in the Antisocial/Aggressive ones $(r=.527, p=.002)$ and in those who show Social Avoidance ( $r=.401, p=.028)$ and Exteriorized Problems $(r=.389, p=.031)$. Problems on the Seeking level are more prevalent in the Self-centred/Explosive ones $(r=.498, p=.004)$, in the AntisociallAggressive ones $(r=.546, p=.002)$ and in those who have Excessive Attention/Activity Problems $(r=.567, p=.001)$ and Exteriorized Problems $(r=.580, p=.001)$.

In the sample under study, it was observed that those who have problems of Planning and Ideas show less Social Cooperation $(r=-.383, p=.033)$, less

Table 4: Pearson Correlation: Relation between dimensions of Sensory Processing Measure - School form VS Behaviour Problems

\begin{tabular}{|c|c|c|c|c|c|c|c|c|}
\hline & & $\begin{array}{l}\text { Self-centred } \\
\text { Explosive }\end{array}$ & $\begin{array}{c}\text { Excessive } \\
\text { Attention/Activity } \\
\text { problems }\end{array}$ & $\begin{array}{l}\text { Antisocial } \\
\text { Aggressive }\end{array}$ & $\begin{array}{c}\text { Social } \\
\text { Avoidance }\end{array}$ & $\begin{array}{c}\text { Anxiety } \\
\text { Somatic Problems }\end{array}$ & Internalized & Externalized \\
\hline Social participation & $\mathrm{R}$ &, $566^{* *}$ & ,680** &, $571^{* *}$ &, $623^{* *}$ &, $465^{* *}$ &, $594^{* *}$ &, $650^{* *}$ \\
\hline Vision & $\mathrm{R}$ &, $510^{* *}$ &, $689^{* *}$ &, $580^{* *}$ &, $600^{* *}$ &, $502^{\star \star}$ &, $607^{\star \star}$ &, $646^{\star *}$ \\
\hline Hearing & $\mathrm{R}$ &, $540^{* *}$ &, $712^{* *}$ &, $615^{* *}$ &, $626^{* *}$ &, $632^{* *}$ &, $698^{* *}$ & $671^{* *}$ \\
\hline Touch & $\mathrm{R}$ &, $478^{* *}$ &, $470^{* *}$ &, $450 *$ &, $665^{* *}$ & ,634** &, $711^{* *}$ &, $489^{* *}$ \\
\hline Body Consciousness & $\mathrm{R}$ & ,620** &, $696^{* *}$ &, $671^{* *}$ &, $400^{* *}$ &, $391^{* *}$ &, $431^{* *}$ &, $706^{* *}$ \\
\hline Balance & $\mathrm{R}$ &, $264^{* *}$ &, $374^{* *}$ &, $350^{* *}$ &, $587^{* *}$ &, $532^{* *}$ &, $613^{* *}$ &, $354^{* *}$ \\
\hline Planning and Ideas & $\mathrm{R}$ &, $384^{* *}$ &, $517^{* *}$ &, $500^{* *}$ &, $680^{* *}$ &, $495^{* *}$ &, $644^{* *}$ &, $503^{* *}$ \\
\hline Total & $\mathrm{R}$ &, $590^{* *}$ &, $713^{* *}$ & ,622** &, $730^{* *}$ &, $635^{* *}$ &, $751^{* *}$ &, $687^{* *}$ \\
\hline
\end{tabular}


Social Autonomy $(r=-.537, p=.002)$, less Social Interaction $(r=-.402, p=.028)$ and more Social Avoidance $(r=.515, p=.004)$; and that the problems on the level of Ideation are associated with less Social Autonomy $(r=-.402, p=.025)$ and more Social Avoidance $(r=.372, p=.043)$. No significant correlations were found between Postural Control and skills and behaviour problems.

\section{DISCUSSION}

The analysis of the results indicated that sensory processing problems are more frequent in the kindergarten context and, although literature about the prevalence of sensory dysfunction in both contexts is scarce, Ahn, Miller, Milberger and McIntosh (2004) estimated that, according to parent's reports, 5,3\% of the children in a suburban public school's kindergarten matched the criteria for sensory processing dysfunction [15].

The results also pointed out that, in the home context, problems at the Touch and Balance level were the most frequent, which can be sustained by the fact that difficulties in sensory processing in children have a significant impact in the family relationships and in the parent/child relationship patterns [8], and they may also contribute to a greater inhibition in the proximity and touch between them [23]. Furthermore, professionals and parents have realized that these sensory difficulties can also affect cognitive and sensorimotor development [12, 13, 24], which can explain why balance is affected. In kindergarten, problems at the level of Social participation and Vision were more frequent. In fact, the school context enables and increases social development and it is therefore easy to predict that any sensory change existing in the child may have implications for the level of interaction with peers. This fact is evidenced by several researchers of the area $[5,12,13,24]$, who demonstrated that difficulties in sensory processing affect the child's ability of engaging in social interaction, communication and daily life skills. The analysis of the differences between both contexts showed that the problems with Social participation, Vision, Body Awareness and Planning and Ideas are more common in the kindergarten context than in the home context. These differences can be explained by the discrepancy between the adults' expectations towards daily routines at home and in the kindergarten [25].

When analysing social skills, it was noted that most of the sample has good social skills, specially in Social Interaction and Social Cooperation. However, it is important to refer that a good range of social skills does not ensure a socially competent performance, although the quality of interpersonal relationships may influence the social development of children at an early age [9]. With regard to behaviour problems, with the exception of the SBP Excessive Attention/Activity Problems dimension, most of the sample has moderate or high behaviour problems, in all dimensions analysed. However, it is in the SBP Anxiety Somatic Problems dimension where the biggest problems are; internalized behaviour problems are more evident than externalized ones. The relation between sensory problems and behaviour problems is documented [4-6]; being also proven in this study, with the presence of behaviour problems accompanying the high prevalence of sensory problems in this sample.

The analysis of the correlations of the SPM-P dimensions (Social participation, Vision, Hearing, Touch, Body Awareness, Balance, Planning and Ideas and Total) and the dimensions related to behaviour problems revealed that the greater the sensory difficulties, the greater the behaviour problems.

It has also been confirmed that the greater the sensory problems, the lower the social skills. The stronger correlations were seen between Social Participation and Social cooperation, and Autonomy and Social interaction. The quality of the interpersonal relationships influences social development of children of younger ages. These results are consistent with the study carried out by Ben-Avi, Almagor and Engel-Yeger (2012), by also finding a positive association between sensory processing disorders and interpersonal relationships in adults [26].

The correlations between the vulnerability systems in sensory integration in kindergarten and Social Skills and Behaviour Problems of the sample with Some Problems and definite dysfunction, indicated that the most Hyperresponsive ones show less Autonomy, are more AntisociallAggressive, show more Social Avoidance, more Anxiety/Somatic Problems and more Internalization and Externalization Problems. These results corroborate the literature, in as much as sensory hyperresponsiveness is highly associated with early internalization and exteriorization behaviour problems and poorly developed adaptative social behaviours [27]. In the area of internalization, socioemotional problems are expressed through symptoms of anxiety and depression [7, 28]. Hyperreactivity often manifests through aggressive behaviours or social avoidance $[21,28]$. 
As for the Hyporesponsive ones, they show less Social Cooperation, less Social Autonomy, less Social Interaction and more Social Avoidance. Hyporesponsiveness is characterized by the lack of an expectable response or apathy/indifference to sensory experience [21, 29, 30]. Some researchers also found an association between hyporesponsiveness and poor academic performance and social functioning [31, 32, 33].

The Perception problems prevail in the AntisociallAggressive ones and in those who show Social Avoidance and Exteriorized Problems. Perception is the ability to interpret the meaning of sensory input and the need for an effective use of the feedback from internal and environmental sensory information. Perception problems may also be connected with modulation problems [21].

As for Seeking problems, they are more frequent in the Self-centred/Explosive ones, in the AntisociallAggressive ones and in those who show more Excessive Attention/Activity Problems and Externalized Problems. Sensory seeking may co-occur with hyporesponsiveness and hyperresponsiveness; the vulnerability of the items of the measure of sensory processing should be taken into account [21].

Poor motor planning can limit the ability to expand play repertoires or involvement with other people [21]. The present study corroborates these arguments, considering that it was observed that those with problems in Planning and Ideias show less Social Cooperation, less Social Autonomy, less Social Interaction and more Social Avoidance; and that the problems related to Ideation are associated with lower Social Autonomy and greater Social Avoidance.

\section{CONCLUSION}

In this study, a high prevalence of sensory processing issues was observed, both in the home and kindergarten contexts, although these results are more evident in kindergarten.

The existence of a positive relation between behaviour problems and sensory processing issues was noted; hyporesponsive children show greater problems in terms of autonomy and hyperresponsive children have greater difficulties in behaviour regulation.

This study intended to improve the understanding of how difficulties in behaviour and social skills, observed by kindergarten teachers and parents, can be based on difficulties in sensory processing.

In another perspective, the identification and respective intervention in these problems at an early age aims to prevent later problems, which may affect development in general and preschool learnings.

This study demonstrated the importance of detecting sensory processing problems early, allowing parents and educators to better understand the child's performance and thus define, in joint collaboration, strategies and intervention programmes more and more adjusted to the real needs of the children and their families.

\section{REFERENCES}

[1] Piaget J. A psicologia da criança. Porto: Asa 1997

[2] Serrano P. A integração sensorial no desenvolvimento e aprendizagem da criança. Lisboa: Papa-Letras 2016.

[3] Andrade L. Importância do desenvolvimento motor em escolares. Monografia final do curso de licenciatura. Brasilia: Universidade Católica de Brasilia 2011.

[4] Gourley L, Wind C, Henninger EM, Chinitz S. Sensory Processing Difficulties, Behavioral Problems, and Parental Stress in a Clinical Population of Young Children. Journal of Child and Family Studies, 2012; 22(7): 912-21. https://doi.org/10.1007/s10826-012-9650-9

[5] Schaaf RC, Benevides T, Blanche El, Brett-Green BA, Burke JP, Cohn ES, et al. Parasympathetic functions in children with sensory processing disorder. Frontiers in Integrative Neuroscience, 2010; 4: 1-11. https://doi.org/10.3389/fnint.2010.00004

[6] Tabasi F, Aliabadi F, Zarei M, Qorbani M, Rostami R. Survey of Behavioral Problems and Sensory Processing in Children with Attention Deficit/Hyperactivity Disorder. Iranian Rehabilitation Journal, 2016; 14(1): 63-68 https://doi.org/10.15412/J.IRJ.08140110

[7] Ben-Sasson A, Carter AS, Briggs-Gowan MJ. Sensory overresponsivity in elementary school: Prevalence and socialemotional correlates. Journal of Abnormal Child Psychology, 2009; 37: 705-16.

https://doi.org/10.1007/s10802-008-9295-8

[8] Dunn W. The impact of sensory processing abilities on the daily lives of young children and their families: A conceptual model. Infants and Young Children, 1997; 9(4): 23-35. https://doi.org/10.1097/00001163-199704000-00005

[9] Gomes R, Pereira A. Escalas comportamentais para crianças em idade pré-escolar - manual. Aveiro: UA Editora 2016.

[10] Gouze KR, Hopkins J, LeBailly SA, Lavigne JV. Reexamining the epidemiology of sensory regulation dysfunction and comorbid psychopathology. Journal of Abnormal Child Psychology, 2009; 37: 1077-87.

https://doi.org/10.1007/s10802-009-9333-1

[11] Miller LJ, Anzalone ME, Lane SJ, Cermak SA, Osten ET. Concept evolution in sensory integration: a proposed nosology for diagnosis. American Journal of Occupational Therapy, 2007; 61: 135-40.

https://doi.org/10.5014/ajot.61.2.135

[12] Shimizu V, Miranda M. Processamento Sensorial na criança com PHDA: Uma revisão da literatura. Revista Psicopedagogica, 2012; 29(89): 256-268. 
[13] Winsler A, Gregory W. Behavior Problems and Social Skills in Preschool Children: Parent-Teacher Agrrement and Relations with classroom observations. Early Education and Development, 2002; 13(1): 41-58.

https://doi.org/10.1207/s15566935eed1301 3

[14] Major S, Santos M. Aptidões sociais e problemas de comportamento: Retratos das crianças portuguesas de idade pré-escolar. Psicologia: Reflexão e Crítica, 2014; 27(4): 68999.

[15] Ahn RR, Miller LJ, Milberger S, McIntosh DN. Prevalence of parents' perceptions of sensory processing disorders among kindergarten children. American Journal of Occupational Therapy, 2004; 58: 287-93. https://doi.org/10.5014/ajot.58.3.287

[16] Schaaf RC, Roley S. Sensory Integration Applying Clinical Reasoning to Practice With Diverse Popultions. Austin, TX: Pro-Ed 2007.

[17] Reis H, Gomes D, Dixe M. Semantic, conceptual, experiential and idiomatic equivalence of SPMP. Siglo Cero, 2020; 50(4): 61-73. https://doi.org/10.14201/scero20195046173

[18] Merrel KW. Preschool and Kindergarten Behavior Scales. Test Manual. Brandon: Clinical Psychology Publishing Company 1994.

[19] Merrell KW. Social-emotional assessment in early childhood: The Preschool and Kindergarten Behavior Scales. Journal of Early Intervention, 1996; 20: 132-45. https://doi.org/10.1177/105381519602000205

[20] Gomes M, Fernandes P, Dixe A, Pinto B, Sousa M, Batista $S$. Translation and Cross - cultural Adaptation to Portuguese of the Sensory Processing Measure - Prescholl (SPM-P). Research and Networks in Health, 2016; 2: 1-6.

[21] Parham LD. Ecker C, Kuhaneck H, Henry DA, Glennon TJ. Sensory Processing Measure (SPM): Manual. Los Ángeles: Western Psychological Services 2007.

[22] Glennon TJ, Miller KH, Herzberg D. The Sensory Processing Measure-Preschool (SPM-P) - Part One: Description of the Tool and Its Use in the Preschool Environment. Journal of Occupational Therapy, Schools, \& Early Intervention, 2011; 4(1): 42-52.

https://doi.org/10.1080/19411243.2011.573245

[23] Mammen MA, Moore GA, Scaramella LV, Reiss D, Shaw DS, Leve LD, Neiderhiser JM. Infant patterns of reactivity to tactile stimulation during parent-child interaction. Infant Behavior and Development, 2016; 44: 121-32. https://doi.org/10.1016/j.infbeh.2016.06.004
Sears C. Recognizing and coping with tactile defensiveness in young children. Inf Young Children, 1994; 6(4): 46-53. https://doi.org/10.1097/00001163-199404000-00007

[24] Rolley SS, Mailloux Z, Parham LD, Schaaf RC, Lane CJ, Cermak S. Sensory integration and praxis patterns in children with autism. American Journal of Occupational Therapy, 2015; 69: 6901220010p1-6901220010p8. https://doi.org/10.5014/ajot.2015.012476

[25] Ben-Avi N, Almagor M, Engel-Yeger B. Sensory Processing Difficulties and Interpersonal Relationships in Adults: An Exploratory Study. Psychology, 2012; 3(1): 70-77. https://doi.org/10.4236/psych.2012.31012

[26] Aron EN, Aron A. Sensory-processing sensitivity and its relation to introversion and emotionality. Journal of Personality and Social Psychology, 1997; 73: 345-68. https://doi.org/10.1037/0022-3514.73.2.345

[27] Dean EE, Little L, Tomchek S, Dunn W. Sensory processing in the general population: Adaptability, resiliency, and challenging behavior. American Journal of Occupational Therapy, 2018; 72(1): 1-8. https://doi.org/10.5014/ajot.2018.019919

[28] Engel-Yeger B, Dunn W. The relationship between sensory processing difficulties and anxiety level of healthy adults. British Journal of Occupational Therapy, 2011a; 74: 210-16. https://doi.org/10.4276/030802211X13046730116407

[29] Engel-Yeger B, Dunn W. Exploring the relationship between affect and sensory processing patterns in adults. British Journal of Occupational Therapy, 2011b; 74: 456-64. https://doi.org/10.4276/030802211X13182481841868

[30] Ashburner J, Ziviani J, Rodger S. Sensory processing and classroom emotional, behavioral, and educational outcomes in children with autism spectrum disorder. American Journal of Occupational Therapy, 2008; 62: 564-73.

https://doi.org/10.5014/ajot.62.5.564

[31] Lane S, Mailloux Z, Schoen S, Bundy A, May-Benson T, Parham L. Roley S, Schaaf R. Neural Foundations of Ayres Sensory Integration. Brain Sciences, 2019; 9: 153. https://doi.org/10.3390/brainsci9070153

[32] Watson LR, Baranek GT, Roberts JE, David FJ, Perryman TY. Behavioral and physiological responses to child-directed speech as predictors of communication outcomes in children with autism spectrum disorders. Journal of Speech, Language, and Hearing Research, 2010; 53: 1052-1064. https://doi.org/10.1044/1092-4388(2009/09-0096)

Received on 28-6-2020

Accepted on 14-7-2020

Published on 15-7-2020

DOI: https://doi.org/10.12974/2313-1047.2020.07.7

(C) 2020 Oliveira and Reis; Licensee Savvy Science Publisher.

This is an open access article licensed under the terms of the Creative Commons Attribution Non-Commercial License (http://creativecommons.org/licenses/by-nc/3.0/) which permits unrestricted, non-commercial use, distribution and reproduction in any medium, provided the work is properly cited. 